\title{
PERSPEKTYWY ROZWOJU FILOZOFII TOMISTYCZNEJ NA PODSTAWIE SYTUACJI W POLSCE
}

\begin{abstract}
Streszczenie. W artykule poruszono problem perspektyw rozwoju, a tym samym przyszłości filozofii tomistycznej na podstawie sytuacji w Polsce. Otóż taką szansę widzi się dla tej filozofii w badaniach bardziej partykularnych, znajdujących się poza głównym obiektem zainteresowań metafizyki ogólnej. Każdorazowo przybierają one postać metafizyk szczegółowych i stosowanych. Pierwsza z nazw nawiązuje do zawężonego pola badań, druga natomiast jest uzasadniona korzystaniem z dorobku innych nauk filozoficznych, bardziej podstawowych, włącznie z metafizyką ogólną.

Metafizyki tego rodzaju stanowią szeroko pojęte studium tego, co jest najbardziej fundamentalne nie dla bytu jako takiego, ale dla wszelkich podstawowych typów przedmiotów w sferze natury i kultury. Nie stanowią one jednak alternatywy dla metafizyki ogólnej, która bada rzeczywistość w wymiarze transcendentalnym, ponieważ korzystając z jej dorobku, zachowują z nią łączność oraz stanowią jej konieczne dopełnienie. Jako zaś typowe dyscypliny filozoficzne, dające możliwość rozwijania owych metafizyk, podano w artykule filozofię przyrody, antropologię filozoficzną oraz dwie formy filozofii ludzkiego działania, czyli religię i moralność. W ich przypadku wskazywano zarówno na tematy już podjęte przez wielu przedstawicieli myśli tomistycznej w Polsce oraz na te, jakie są możliwe do podjęcia.

Realizacja tych form metafizyki odpowiada nie tylko strukturze rzeczywistości pluralistycznej i jednocześnie powiązanej ze sobą szeregiem zależności, ale też problemom aktualnym, nowym, wymagającym ujęcia gruntownego i całościowego, jakie stwarza dopiero perspektywa metafizyczna, rozpatrywana z pozycji filozofii tomistycznej.
\end{abstract}

Słowa kluczowe: rozwój filozofii tomistycznej, metafizyka szczegółowa i stosowana

1. Wstęp. 2. Filozofia przyrody. 3. Antropologia filozoficzna. 4. Filozofia religii. 5. Etyka.

6. Zakończenie.

\section{WSTĘP}

Jednym z charakterystycznych przejawów współczesnej nauki są - z jednej strony - zjawisko jej postępującego zróżnicowania się, specjalizacji, mnożenia się odrębnych dyscyplin naukowych, 
a z drugiej - próby idące w odwrotnym kierunku, czyli ku integracji, unifikacji nauk. Obie tendencje uważano za cenne, dopełniające się, wpływające razem na rozwój nauki. Pierwsza z nich umożliwia bowiem osiąganie coraz bogatszych i dokładniejszych treści poznawczych, a druga nadaje każdej szczegółowej postaci poznania odpowiednie miejsce i sens w całości wiedzy, niezbędnej m.in. dla celów światopoglądowych ${ }^{1}$.

Podobne zjawiska obserwuje się na gruncie filozofii tomistycznej w Polsce w najnowszym okresie. Otóż dochodziło tu najpierw do niekiedy daleko posuniętej parcelacji tej filozofii - w obrębie tych dyscyplin, które znajdują się poza głównym przedmiotem zainteresowań metafizyki ogólnej. W związku z tym stanem rzeczy uważano je za tzw. metafizyki szczegółowe.

Ich obecność uzasadniano faktem realnego istnienia w świecie pluralizmu bytowego, czyli różnorodnych przedmiotów, ich klas, podklas, posiadających różne zakresy i natury. Można je wszystkie uczynić przedmiotem (materialnym) badań filozoficznych, o ile - jak zaznaczał Stanisław Kamiński - dysponujemy dostatecznie bogatym zespołem empirycznych danych wyjściowych o pewnym typie bytu². To otwiera możliwość prowadzenia wielorakich form refleksji, skoncentrowanych na różnych typach bytu, na ich bardziej zawężonym zakresie, dając w efekcie wiedzę mniej ogólną, ale intelektualnie interesującą, poszerzającą problematykę filozoficzną. Możliwości takich badań pojawiają się równolegle z rozwojem nauk szczegółowych, ze zmianami cywilizacyjnymi oraz $\mathrm{z}$ aktualną sytuacją egzystencjalną człowieka w świecie. Przynoszą one bowiem nowe problemy i wyzwania, wymagające filozoficznego namysłu.

1 Por. S. Kamiński, O podstawach unifikacji nauk, w: Tenże, Metoda i język, red. U. M. Żegleń, Lublin 1994, 435-444.

2 Por. Tenże, Dziedziny teorii bytu, w: Tenże, Jak filozofować?, red. T. Szubka, Lublin 1989, 191. 
Powyższemu zjawisku towarzyszyły jednocześnie próby łączenia i ujednolicania poznania filozoficznego, realizowanego w metafizyce ogólnej i w metafizykach szczegółowych, dzięki czemu otrzymywało się w miarę jednolity typ filozofii o charakterze metafizycznym ${ }^{3}$. Jednym zaś z zasadniczych sposobów takiegoż ujednolicania było wykorzystywanie przez metafizyki szczegółowe danych poznawczych uzyskiwanych $w$ innych naukach, z zasady w bardziej podstawowych, nadrzędnych, z metafizyką ogólną włącznie. W ten sposób metafizyki szczegółowe stawały się w większym lub mniejszym stopniu tzw. metafizykami stosowanymi, interdyscyplinarnymi naukami filozoficznymi, w których pewien ograniczony zakresowo przedmiot badań jest interpretowany, tłumaczony w świetle innych nauk, zwłaszcza w końcowym etapie badań.

Pojęcie metafizyki stosowanej odnosi się zatem wyłącznie do idei tzw. metafizyk szczególowych, do sposobu ich budowania. Nie polega on na partykularyzacji i akomodacji ustaleń metafizyki ogólnej do określonego typu bytu, węższego pod względem zakresu, ale na rozpoczynaniu badań od osobliwych danych przedmiotowych, na ujmowaniu ich w pojęciach ontologicznych właściwych dla tego bytu, by następnie, w ostatecznej fazie badań, skorzystać z klasycznej teorii bytu, zwłaszcza z metafizyki ogólnej. W związku z tym stosuje się w niej - w sposób analogiczny do metafizyki ogólnej - aspekt i metody badań, jej cele, korzysta się nieraz z jej aparatury pojęciowej, ogólnometafizycznych treści w postaci tez i zasad. Dzięki temu uzyskuje się w metafizykach szczegółowych wiedzę nie tylko specyficzną, ale też ostatecznie wyjaśniającą w stosunku do określonego wycinka badanej rzeczywistości.

Postępowanie tego rodzaju jest uzasadnione merytorycznie charakterem realnej rzeczywistości, która jest nie tylko pluralistyczna, jak wspomniano wyżej, ale też w znacznej mierze jednorodna

3 Por. Tenże, O naturze filozofii, w: Tenże, Jak filozofować?, dz. cyt., 49-50. 
i hierarchiczna, harmonijnie powiązana ze sobą na różne sposoby ${ }^{4}$. Stąd też metafizyki szczegółowe, skoncentrowane na własnym, partykularnie pojętym przedmiocie poznania, odwołują się do metod i wyników innych nauk filozoficznych, szerszych zakresowo, a zwłaszcza do metafizyki ogólnej, badającej rzeczywistość w wymiarze najbardziej uniwersalnym, transcendentalnym, umożliwiającym stworzenie jednolitego obrazu świata. Zastosowania tego rodzaju nie odbierają jednak autonomii poszczególnym metafizykom szczegółowym, ponieważ w ich rezultacie uzyskuje się specyficzne treści poznawcze każdej z tych metafizyk ze względu na samodzielny, charakterystyczny dla niej przedmiotowy punkt wyjścia ${ }^{5}$.

Problem metafizyk szczegółowych i stosowanych budził w pewnym okresie czasu spore kontrowersje $\mathrm{w}$ środowisku polskich tomistów, ale działo się to przy unitarnym rozumieniu jedności poznania filozoficznego oraz przy zbyt daleko posuniętym wykorzystywaniu metafizyki ogólnej do analizy partykularnych form bytu, w wyniku czego te ostatnie wiele traca na własnej problematyce, specyfice, autonomii ${ }^{6}$. Wyjaśniano zatem, że jedność refleksji filozoficznej w ramach tomizmu uzyskuje się przede wszystkim za sprawą analogicznie rozumianego aspektu badań, jakim jest fundamentalność podejścia poznawczego: poszukiwanie tego, co jest istotne w strukturze bytu jako takiego lub jego określonej postaci. Przedmiotem tych badań jest zarówno byt realny w sensie ścisłym, rozpatrywany w ogólności lub $\mathrm{w}$ odniesieniu do poszczególnych jego typów, jak ludzkie poznanie i działanie, rzeczywistość znakowa7.

4 Por. Tenże, O podstawach unifikacji nauk, art. cyt., 445.

5 Por. S. Swieżawski, Święty Tomasz na nowo odczytany, Kraków 1983, 21-23; K. Kłósak, Z teorii i metodologii filozofii przyrody, Poznań 1980, 9-10, 103, 119; S. Kamiński, Metody współczesnej metafizyki, w: Tenże, Filozofia i metoda, red. J. Herbut, Lublin 1993, 107, 117.

6 Por. K. Kłósak, Z teorii i metodologii filozofii przyrody, dz. cyt., 8-13, 49-96.

7 Por. S. Kamiński: Osobliwość metodologiczna teorii bytu, dz. cyt., 76-77; Tenże, Współczesne metody metafizyki, w: Tenże, Filozofia i metoda, dz. cyt., 124; M. A. Krąpiec, 
Tak ogólnie zarysowany program partykularyzacji i unifikacji filozofii tomistycznej w formie metafizyk szczegółowych i stosowanych stanowi - zdaniem autora tegoż artykułu - jeden ze sposobów uaktualnienia i rozwijania tej filozofii, obok dotychczas powszechnie proponowanych, czyli poprzez otwarcie się na dorobek nauk empirycznych i formalnych oraz innych współczesnych kierunków filozoficznych. Sposób ten, chociaż był dość powszechnie stosowany, to nie został do tej pory w pełni podkreślony i doceniony. Można żywić nadzieję, że jego wykorzystanie sprawi, że tomizm nie ograniczy się tylko do powtarzania za św. Tomaszem jego poglądów, ale zgodnie z życzeniem wielu jego zwolenników stanowić będzie pewien typ filozofii w stylu filozofii klasycznej, nawiązującej do Arystotelesa i Akwinaty, wykorzystującej jej niewątpliwy dorobek w zakresie refleksji ogólnej i fundamentalnej, a jednocześnie aktualnej, otwartej na bardziej konkretne problemy współczesności, interpretującej ją realistycznie i całościowo, zgodnie $\mathrm{z}$ wymogami prawdy ${ }^{8}$.

Sposób ten był i może być dalej urzeczywistniany we wszystkich dyscyplinach zakresowo węższych w stosunku do metafizyki ogólnej. W tej pracy uwzględniono tylko niektóre $\mathrm{z}$ nich jako typiczne; te, które - jak się wydaje - stwarzają największe możliwości ich rozwijania w duchu metafizyk szczegółowych i stosowanych, biorąc za podstawę analizy sytuację w polskim tomizmie. Chodzi najpierw o filozofię przyrody i antropologię filozoficzną, które należą - obok metafizyki ogólnej i filozofii Boga - do nauk najbardziej fundamentalnych pod względem zakresu i sposobu istnienia przedmiotu ich badań. Następnie idzie o filozofię religii i etykę, będące dwoma

Człowiek - Kultura - Uniwersytet, red. A. Wawrzyniak, Lublin 1982, 265-266; E. Morawiec, Podstawowe zagadnienia metafizyki klasycznej, Warszawa 1998, 44.

8 Por. M.A. Krąiec, Z.J. Zdybicka, O tomistycznej drodze poznania Boga, w: Aby poznać Boga i człowieka, cz. I: O Bogu dziś, red. B. Bejze, Warszawa 1974, 75; A. Maryniarczyk, Tomizm egzystencjalny a dziś filozofii, w: Filozofować dziś. Z badań nad filozofią najnowszą, red. A. Bronk, Lublin 1995, 299-300; Tenże, Aktualność tomizmu, w: Wprowadzenie do filozofii, red. E. Łupina i inni, Lublin 1998, 705-739. 
ważnymi przejawami filozofii ludzkich działań i wytworów, niezwykle ważnymi z punktu widzenia rozpatrywanej filozofii, biorącymi pod uwagę aktywność religijną i moralną człowieka. Nie stanowią one oczywiście jedynych form działania człowieka, na przykładzie których można pokazać proces rozwoju filozofii w aspekcie powstawania jej nowych form, bardziej partykularnych, powiązanych z innymi ideami tomizmu (może np. chodzić o różne dyscypliny z filozofii poznania lub o historiozofię).

\section{FILOZOFIA PRZYRODY}

Proces parcelacji i zarazem unifikacji filozofii tomistycznej w postaci metafizyk szczegółowych i stosowanych wyraźnie jest widoczny na gruncie filozofii przyrody. Nawet najogólniej rozumiana, posiadała ona takiż status ze względu na specjalny typ bytu, jaki jest przedmiotem jej zainteresowań - zakresowo węższy i jednocześnie bogatszy treściowo wobec perspektywy metafizyki ogólnej - wymagający jednak dla swojej adekwatnej charakterystyki uwzględnienia szerszej perspektywy poznawczej, obecnej w metafizyce ogólnej, a także w całym systemie tomistycznym (najogólniej pojęty kierunek badań, zasadnicza metoda oraz pewne tezy epistemologiczne i ontologiczne, służące m.in. jako narzędzia interpretacyjne danych empirycznych) 9 .

Proces partykularyzacji postępuje tu dalej i obejmuje zasadnicze obszary i zjawiska przyrody, stanowiąc bardziej szczegółowe formy omawianej dyscypliny. Jest on generowany wzrostem i postępem wiedzy naukowej na temat przyrody, oceną aktualnego stanu natury lub też osobistymi zainteresowaniami w stosunku do jakiegoś fragmentu

9 Por. K. Kłósak, Z teorii i metodologii filozofii przyrody, dz. cyt., 40, 124-127, 136-140; Z. Hajduk, Koncepcje filozofii przyrody, w: Filozofia przyrody, red. S. Janeczek i inni, Lublin 2013, 15-22; A. Lemańska, Filozofia przyrody a nauki przyrodnicze, w: Filozofia przyrody, dz. cyt., 46-49; M. Heller, Filozofia przyrody. Zarys historyczny, Kraków 2004, 234-235; Tenże, Logos wszechświata. Zarys filozofii przyrody, Kraków 2013, 255; J. Mączka, Uwagi na temat przedmiotu filozofii przyrody, w: Filozofia przyrody, dz. cyt., 63-64. 
rzeczywistości przyrodniczej. Rozpatrując jednak określony fragment tej rzeczywistości, korzysta się przy tej okazji z ustaleń innych nauk filozoficznych, dając w rezultacie swoiste metafizyki stosowane, nauki interdyscyplinarne ${ }^{10}$.

Przykładem jest tzw. praktyczna filozofia przyrody (filozofia ekologiczna, środowiskowa), powstała w następstwie oceny aktualnego stanu środowiska naturalnego i z potrzeby jego ochrony wskutek działalności człowieka ${ }^{11}$. Z uwagi na to, że nauka ta dotyczy dość szczegółowej sprawy, jeśli chodzi o zakres zainteresowań filozofii przyrody, dlatego też bywa rozumiana jako jedna z subdyscyplin klasycznej filozofii przyrody. Podkreśla się przy jej najogólniejszej charakterystyce, że sens jej istnienia na gruncie filozofii tomistycznej polega na więzi z innymi naukami filozoficznymi, na funkcjonowaniu jej jako nauki interdyscyplinarnej. Zauważano, że w odpowiedni sposób uprawiana, nie może ona posiadać pełnej autonomii, ponieważ powinna uwzględniać szerszą perspektywę filozoficzną, na którą składają się: metafizyka ogólna, ukazująca przyrodę i człowieka w niej żyjącego w perspektywie całości bytu, dająca wizję całościową, realistyczną, pluralistyczną i hierarchiczną; antropologia filozoficzna, ukazująca człowieka jako istotę materialno-duchową, transcendentną wobec przyrody; filozofia kultury, analizująca sens ludzkiej twórczości; w końcu konieczna jest etyka, dająca właściwą teorię moralnego postępowania, odpowiadającą godności osoby ludzkiej. Brak takiego szerszego i pogłębionego odniesienia może prowadzić bowiem do zafałszowania obrazu człowieka w duchu materializmu i naturalizmu oraz do swoistej „sakralizacji” przyrody ${ }^{12}$.

10 Por. Z. Hajduk, Koncepcje filozofii przyrody, art. cyt., 15-16.

11 Por. A. Lemańska, Praktyczna filozofia przyrody alternatywą klasycznej filozofii przyrody?, Studia Philosophiae Christianae 33(1997)1, 133-138.

12 Por. A. Maryniarczyk, Metafizyka w ekologii, Lublin 1999, 13-27, 60-178; Z. Hajduk, Filozofia przyrody, filozofia przyrodoznawstwa, metakosmologia, Lublin 2007, 43-47; A. Ganowicz-Bączek, Spór o etykę środowiskową, Kraków 2009; J. Łukomski, Próba zbudowania chrześcijańskiej etyki środowiska naturalnego, Kielce 2000; Z. Kieroń, Z. 
Poza wymienionymi już formami metafizyki szczegółowej i stosowanej w obrębie filozofii przyrody, jej inne przejawy są widoczne przy rozpatrywaniu przynajmniej niektórych najważniejszych zjawisk przyrodniczych, dając tym samym podstawę do kształtowania się quasi-samodzielnych dyscyplin $\mathrm{z}$ tego zakresu. Szczególnie jest to dostrzegalne na gruncie filozofii przyrody ożywionej, zainteresowanej zagadnieniem życia, problemem od dawna obecnym w religii, filozofii i w nauce. Zjawisko to, rozpatrywane w ramach biofilozofii, stanowi pewną postać metafizyki szczegółowej i zarazem stosowanej, nauki interdyscyplinarnej, która korzysta nie tylko z rozmaitych treści ściśle filozoficznych (metafizycznych), ale też uzyskiwanych ze strony współczesnych nauk przyrodniczych.

Przykładem jest opis tego, czym jest życie. Odnajduje się w tym opisie podstawowe pojęcia z metafizyki ogólnej, odniesione do rozpatrywanego zjawiska, jak istota, typ i struktura bytu, sposób istnienia. Znalazło to swój wyraz w definicji, która określa życie jako sposób istnienia bytu; ruch wsobny (przypadłość) odpowiednich substancji, które w myśl teorii pluralizmu bytowego oraz hylemorfizmu posiadają trzy podstawowe stopnie ${ }^{13}$. Podobna sytuacja panuje w związku $\mathrm{z}$ genezą życia i z ewolucją biokosmosu, a więc z zagadnieniami wyrosłymi na bazie teorii na temat ewolucji kosmosu i życia. Choć traktuje się te zjawiska jako charakterystyczne dla świata przyrody, to jednak mimo wszystko nie wyczerpują one bogactwa procesów zachodzących w tym świecie i tym samym stanowią partykularną formę analizy obecnego w nim bytu. Dla jego zaś adekwatnej charakterystyki zachodzi potrzeba wykorzystania danych z dwóch zasadniczych dyscyplin filozoficznych. Najpierw jest nią filozofia przyrody,

Wróblewski, Filozofia przyrody a współczesna kultura, w: Filozofia przyrody, dz. cyt., 283-299.

13 Por. M. Wnuk, A. Zykubek, Pojęcie, natura i geneza życia, w: Filozofia przyrody, dz. cyt., 71, 76; A. Latawiec, Jak nauczać filozofii przyrody ożywionej?, w: Filozofia przyrody, dz. cyt., 448-451; P. Lenartowicz, Czy empiria biologiczna ma jakieś znaczenie dla filozofii człowieka?, w: Antropologia, red. S. Janeczek, Lublin 2010, 237-272. 
na gruncie której porusza się m.in. kwestie struktury bytu materialnego, determinizmu i indeterminizmu, pochodzenia praw przyrody; następnie jest nią metafizyka ogólna, w której pojawiają się pojęcia Pierwszej Przyczyny i przyczyn wtórnych, bytów przygodnych i ich struktury, proporcjonalności przyczyny i skutku ${ }^{14}$.

Innym przykładem bardziej szczegółowych badań w obrębie filozofii przyrody jest filozoficzna analiza zjawiska cudu, fenomenu stosunkowo rzadkiego i akcydentalnego w stosunku do całości zjawisk przyrodniczych czy religijnych, łamiącego naturalny porządek rzeczy, burzącego pewną regularność i powtarzalność zjawisk, odmiennego wobec praw funkcjonujących $\mathrm{w}$ przyrodzie. Jak pokazują to jednak konkretne prace naukowe $\mathrm{z}$ dziedziny filozofii przyrody - także z filozofii religii - opis wspomnianego fenomenu może stanowić swoistą metafizykę szczegółową (filozofię cudu), a zarazem metafizykę stosowaną - refleksję o charakterze interdyscyplinarnym. Na jego charakterystykę wpływają bowiem: najogólniejsza i najbardziej fundamentalna wizja przyrody, jej własności (porządek, jednorodność, przyczynowość, jednostajność); filozofia nauki - głównie przyrodoznawstwa - która badając podstawy nauk przyrodniczych, dokonuje charakterystyki i interpretacji praw przyrody; w grę wchodzą ponadto filozofia religii i Boga, które rozpatrują cel życia ludzkiego w perspektywie określonej idei Boga, opatrzności, przyczynowości sprawczej i celowej ${ }^{15}$.

14 Por. T. Wojciechowski, Zarys filozofii przyrody ożywionej, Opole 1997, 19-24, 37-123; K. Kloskowski, Filozofia ewolucji i filozofia stwarzania, t. 1: Między ewolucją a stwarzaniem, Warszawa 1999, 53-102, 269, 270-281; J. Buczkowska, A. Lemańska, Wprowadzenie, w: Stwarzanie i ewolucja, red. J. Buczkowska, A. Lemańska, Warszawa 2002, 7-18; W. Dyk, Kreacja i ewolucja w świetle praw przyrody, w: Stwarzanie i ewolucja, dz. cyt., s. 56-78; S. Ziemiański, Celowość według Arystotelesa i św. Tomasza z Akwinu, w: W poszukiwaniu istoty życia. Pamięci ks. prof. Szczepana Ślagi, red. G. Bugajak, A. Latawiec, Warszawa 2005, 159-176; M. Wnuk, A. Zykubek, art. cyt., 71-85; J. Zon, Ewolucja i ewolucjonizm, w: Filozofia przyrody, dz. cyt., 87-113.

15 Por. A. Świeżyński, Prawa nauki a możliwość zachodzenia zjawisk cudownych w kontekście zagadnienia naukowej niewyjaśnialności cudu, w: Filozofia przyrody, dz. cyt., 413-439; M. Rusecki, Cud w chrześcijaństwie, Lublin 1996. 


\section{ANTROPOLOGIA FILOZOFICZNA}

Kolejne pole do rozwijania filozofii tomistycznej w interesujący nas sposób stanowi antropologia filozoficzna, traktowana powszechnie w gronie tomistów jako węzłowa część refleksji filozoficznej, a ponadto jako szczegółowa i stosowana metafizyka bytu ludzkiego, rozpatrująca ten byt $\mathrm{w}$ aspekcie jego wewnętrznej struktury i podstawowych zewnętrznych uwarunkowań, ukazując w rezultacie całościowy obraz człowieka, spójny z ogólnym poglądem na świat ${ }^{16}$.

Zauważyć można, że zasadniczym sposobem jej rozwoju miało być udoskonalanie empirycznego punktu wyjścia tej dyscypliny, czyli coraz dokładniejszy i wszechstronniejszy opis człowieka od strony doświadczalnej, jaki można uzyskać za pomocą rezultatów nauk szczegółowych i niektórych analiz filozofów współczesnych. Podstawowe ustalenia uzyskiwane tym sposobem - zawarte w tzw. fenomenologii człowieka - miały występować w funkcji przesłanek $\mathrm{w}$ rozumowaniu redukcyjnym, prowadzących do wniosku na temat pochodzenia bytu ludzkiego oraz filozoficznie rozumianej jego natury (struktury ontycznej, substancjalnej jedności oraz pozycji egzystencjalnej wśród pozostałych bytów). Takie podejście metodologiczne bywało niekiedy wyrażane językowo w tytule podstawowej części wykładu $z$ antropologii filozoficznej: Od fenomenologii do metafizyki cztowieka ${ }^{17}$. Taki był m.in. sposób i cel analiz filozoficznych poczynionych w dziele Karola Wojtyły Osoba i czyn ${ }^{18}$.

Kolejne możliwości rozwijania tej nauki tkwią w dalszym procesie partykularyzacji jej przedmiotu. Obejmuje on - analogicznie do zjawiska biogenezy w ramach filozofii przyrody - antropogenezę, czyli złożoną i szeroko opracowywaną kwestię pochodzenia człowieka

16 Por. S. Kowalczyk, Antropologia filozoficzna - koncepcja, metody, problematyka, w: Antropologia, dz. cyt., 22-23.

17 Por. Tenże, Zarys filozofii człowieka, Sandomierz 2002, 27.

18 Por. K. Wojtyła, Osoba i czyn, Kraków 1985, 12-30. 
(ciała i duszy), obejmującą zagadnienia ewolucji, jej zasięgu, przyczyny bliższej i ostatecznej (istnienia i natury działającego Boga); stosunku ciało - dusza; natury tego, co duchowe i fizyczne ${ }^{19}$. Przede wszystkim chodzi o różne aspekty życia ludzkiego zawarte we wspomnianej już fenomenologii człowieka, która po ontologicznej interpretacji w myśl tomistycznej wizji rzeczywistości uzyskuje status poznania filozoficznego, odpowiadający sferze przypadłości w stosunku do substancji, jaką jest byt ludzki. Jakkolwiek sfera przypadłości stanowi z definicji typ bytu niesamodzielnego i zmiennego, to jednak w ramach tej fenomenologii traktuje się je jako cechy względnie stałe, konieczne, istotne, konstytutywne dla człowieka, wyodrębniane w abstrakcji fizycznej lub ewentualnie w oglądzie ejdetycznym. Chodzi tu o grupy zjawisk związanych z cielesnością, emocjami, rozumnością, wolnością, językiem, pracą, wspólnotowością, moralnością, religijnością.

Bardziej dokładna analiza tych istotnych cech ludzkich, ubogacana m.in. wraz z rozwojem nauk empirycznych, daje asumpt do sformułowania metafizyk szczegółowych, czyli dyscyplin podrzędnych, bardziej partykularnych w stosunku do filozofii człowieka, rozumianej jako refleksja skupiona na indywidualnym bycie ludzkim. W takiej analizie - mającej postać nauki interdyscyplinarnej - stosuje się obok uogólniających syntez o charakterze empirycznym, dane nadrzędnych i związanych z nimi dyscyplin: filozofii przyrody, antropologii filozoficznej oraz metafizyki ogólnej ${ }^{20}$.

Za przykład może służyć filozofia społeczna, czyli swoista metafizyka bytu społecznego, ponieważ generuje różne poddyscypliny,

19 Por. K. Kłósak, Dusza ludzka w perspektywach filozofii przyrody i metafizyki, Analecta Cracoviensia 10(1978), 29-47; W. Dyk, Geneza duszy ludzkiej w kontekście teorii ewolucji, w: Metafizyczne i antropologiczne założenia filozofii religii, red. P. Moskal, Lublin 2007, 103-134.

20 Por. A.B. Stępień, W poszukiwaniu istoty człowieka, człowieka (z fenomenologii i metafizyki ludzkiego bytu), w: Aby poznać Boga i człowieka, cz. II - O człowieku dziś, red. B. Bejze, Warszawa 1974, 64-66; K. Kłósak, Z teorii i metodologii filozofii przyrody, dz. cyt., 154-155; S. Kowalczyk, Antropologia filozoficzna - koncepcja, metody, problematyka, art. cyt., 21-25. 
podejmujące filozoficzną refleksję nad państwem, polityką, formami władzy (np. demokracją), narodem, a nawet nad tak wąską i jednocześnie ważną wspólnotą, jaką jest rodzina. Niezależnie od zakresu ich „szczegółowości”, wyznaczanym specyficznym charakterem typu bytu społecznego, wykorzystuje się w nich zasady właściwe dla metafizyki ogólnej oraz innych dyscyplin, przystosowane do własnego i zawężonego pola badań. Zasadnicza struktura tych wspólnot jest więc tłumaczona na sposób metafizyki szczegółowej i stosowanej przy wykorzystaniu pierwszych zasad bytu i myśli; kategorii bytu (substancje i przypadłości, wśród których znajdują się relacje); elementów struktury bytu (zjawiska i istota rzeczy); własności transcendentalnych (np. jedność); pojęcia osoby ludzkiej, natury człowieka; wykazu jego istotnych cech odróżniających od bytów przynależnych całkowicie do świata przyrody; przyczyn bytu społecznego (immanentne i transcendentne); pojęcia dobra wspólnego; zasad etycznych; elementów filozofii kultury lub teorii uczestnictwa ${ }^{21}$. Warto wspomnieć, że taż teoria uczestnictwa w wersji Wojtyły może być wielce pomocna w zrozumieniu istoty (eidos) Kościoła, jaką nakreślał Marian Jaworski ${ }^{22}$.

Społeczny wymiar bytu ludzkiego nie jest oczywiście jedynym, jaki można wziąć pod uwagę w ramach zainteresowań metafizyki szczegółowej i stosowanej. Może ona objąć zagadnienia uczuć (miłości), wolności, świadomości czy nieśmiertelności, mające bogatą historię w myśli filozoficznej, aktualne w naszych czasach, które są

21 Por. M. Gogacz, Człowiek i jego relacje. Materiały do filozofii człowieka, Warszawa 1985, 140-189; Tenże, Życie społeczne w duchu Ewangelii. O nauczaniu społecznym Kościoła z Mieczysławem Gogaczem rozmawia Stanisław Krajski, Episteme 59(2006), red. A. Andrzejuk, Olecko 2006, 34-39; M.A. Krąpiec, Człowiek i polityka, red. A. Maryniarczyk, Lublin 2007, 23-125, 215-239; Tenże, Człowiek i prawo naturalne, Lublin 2009, 99-191.

22 Por. M. Jaworski, Od filozofii religii do eidos Kościoła. Wybór pism filozoficznych, t. 3, red. K. Mikucki, Kraków 2018, 167-169. 
mocno osadzone w tomistycznej wizji przyrody, człowieka i Boga, hierarchii wartości, postępowania moralnego ${ }^{23}$.

\section{FILOZOFIA RELIGII}

Perspektywy rozwoju filozofii tomistycznej za sprawą wykorzystania idei metafizyki szczegółowej i stosowanej dostrzegalne są w filozofii religii, która - rozpatrywana najogólniej - jest refleksją nad jedną z wielu czynności ogólnoludzkich, którą można opisać i wyjaśnić na podstawie ustaleń antropologii filozoficznej i metafizyki ogólnej (filozofii Boga).

Przed tego rodzaju metafizyką otwierają się dalsze możliwości badań, bardziej szczegółowe, z których wielu tomistów korzystało. Są one inspirowane niekiedy współczesną myślą filozoficzną spoza tomizmu, głównie z obszaru fenomenologii. Te bardziej szczegółowe analizy filozoficzne w stosunku do religii polegają na tym, że rozpatruje się je nie tyle w wymiarze uniwersalnym, ogólnym, w aspekcie tego, co jest jej wspólne, ile w zakresie ograniczonym do konkretnej jej formy lub do towarzyszących jej zjawisk, do tego, co jest w nich swoiste. Takie podejście było usprawiedliwiane m.in. faktem, że prawda religijna różnicuje się ze względu na różne religie, prezentujące własne i odmienne koncepcje Boga, Jego stosunku do człowieka i świata ${ }^{24}$. Zwracano uwagę, że taka rzeczywistość jak „,religia w ogóle" nie istnieje realnie jako samodzielny byt społeczny, ale jest abstraktem, stąd też przedmiotem badań filozofii religii w punkcie wyjścia mogą (powinny) być konkretne religie ${ }^{25}$. W związku z tym koncentrowano się głównie na chrześcijaństwie (katolicyzmie), czego

23 Por. S. Kowalczyk, Zarys filozofii człowieka, dz. cyt., 55-72, 88-125,

24 Por. M. Jaworski, Problem filozofii religii, w: Studia z filozofii Boga, religii i człowieka, red. J. Sochoń, Warszawa 2002, 113-115.

25 Por. A. Bronk, Metodologiczny status nauk o religii, w: Filozofia religii, red. S. Janeczek, Lublin 2012, 15-37; P. Moskal, Religia i prawda. Filozofia religii, apologia religii, diagnostyka religii, w: Filozofia religii, dz. cyt., 317. 
najbardziej znane i doniosłe przykłady można znaleźć w refleksji Mariana Jaworskiego, Piotra Moskala i Mieczysława Gogacza.

Jaworski pokazuje, że w ramach filozofii religii można podjąć szereg tematów ważnych i zarazem bardziej szczegółowych. Obejmują one badania istoty chrześcijaństwa w aspekcie tego, czym jest ono w swej niepowtarzalności, swoistości wobec innych religii oraz tego, co świeckie; istoty Kościoła, jego eidos; istoty modlitwy, rozpatrywanej od strony analizy językowej; wreszcie istoty życia zakonnego obecnego w chrześcijaństwie, szczególnie w Kościele katolickim. Analizy te były niejednokrotnie przeprowadzane w kontekście szerszych perspektyw poznawczych, jakimi dysponują antropologia filozoficzna i filozofia Boga ${ }^{26}$.

Podobny kierunek badań widoczny jest u Moskala, zainteresowanego przede wszystkim opisem religii chrześcijańskiej (katolickiej), traktowanej jako analogat główny zjawiska religijności, rozpatrywany w aspekcie jej prawdy, przy wykorzystaniu pewnych danych filozofii Boga, antropologii filozoficznej i opartej na nich etyki ${ }^{27}$. Wskazuje więc, że prawdziwa z punktu widzenia filozoficznego jest ta religia, która respektuje prawdę o istnieniu i naturze jednego Boga oraz człowieka, czyli bytów osobowych, z których pierwszy z wymienionych jest Absolutem w sensie bytowym i etycznym, a drugi bytem przygodnym (odpowiednio ustrukturyzowany $z$ duszy i ciała), pomiędzy którymi zachodzą relacje osobowe ${ }^{28}$. Metafizyczny kontekst posiada

26 Szerzej na ten temat traktują prace: M. Jaworski, Od filozofii religii do eidos Kościoła, w: Wybór pism filozoficznych, t. 3, red. K. Mikucki, Kraków 2018, 37-85, 149-181; K. Mikucki, Kierunki badań filozoficznych nad religią w ujęciu Mariana Jaworskiego, Studia Leopoliensia 11(2018), 39-66.

27 Por. P. Moskal, Religia i prawda. Filozofia religii, apologia religii, diagnostyka religii, art. cyt., 317-335.

28 Por. tamże, 317-319; Tenże, Problem genezy religii. Aspekty filozoficzne i teologiczne, w: Filozofować w kontekście teologii. Religia - Natura - Łaska, red. P. Moskal, Lublin 2003, 9-19; Tenże, Pytanie o religię prawdziwą, w: Filozofować w kontekście teologii. Problem religii prawdziwej, red. P. Moskal, Lublin 2004, 11-23; Tenże, Teza teistyczna, w: Filozofować w kontekście teologii. Problem religii prawdziwej, dz. cyt., 25-36; Z. J. Zdybicka, 
u niego także analiza tak elementarnego fenomenu chrześcijaństwa, jakim jest Objawienie, rozpatrywane od strony filozofii w aspekcie jego konstytutywnych elementów (istoty) oraz w perspektywie czterech podstawowych przyczyn: sprawczej (głównej i instrumentalnej), celowej, materialnej i formalnej29.

Jeszcze innym uszczegółowieniem refleksji filozoficznej nad religią jest mistyka, będąca przykładem filozofii chrześcijańskiej, która za przedmiot analizy bierze zjawisko nadprzyrodzone, niestanowiące wprost przedmiotu poznania zmysłowo-umysłowego, dokonując filozoficznego opisu występującego tu typu doświadczenia i struktury fenomenu. Metafizyczny (filozoficzny) wymiar takiegoż filozofowania wyraża się w jego istotowej identyfikacji w tym, czym mistyka jest i powinna być. Dokonuje się tego przy pomocy użycia kategorii bytu relacyjnego, który ma swój substancjalny podmiot (Bóg), przedmiot (człowiek) oraz podstawę w inicjatywie Boga, chcącego taką relację zapoczątkować i w niej uczestniczyć. Dla pełni tegoż opisu konieczna jest także filozoficzna znajomość osoby ludzkiej, jej struktury i przyczyn zewnętrznych (szczególnie Boga jako Osoby) ${ }^{30}$.

W ramach metafizyk szczegółowych i stosowanych na terenie filozofii religii jest miejsce także na inne zjawiska, które można rozpatrywać w myśl zasad tomizmu, w kontekście jego różnych dyscyplin filozoficznych. Dotyczy to filozofii wiary, stanowiącej ważną część filozoficznych rozważań, powiązanej nie tylko z filozofią religii, ale też z metafizyką ogólną, z teorią poznania, z teodyceą oraz z filozofią człowieka (filozofią społeczną i kultury). Analogicznie przedstawia się sprawa np. z nadzieją, która może stanowić elementarny dział filozofii religii, czego przykłady znajdujemy w filozofii współczesnej.

Udział filozofii w określaniu prawdziwości religii, w: Filozofować w kontekście teologii. Problem religii prawdziwej, dz. cyt., 37-49.

29 Por. P. Moskal, Filozofia Objawienia, w: Objawienie, red. P. Moskal, Lublin 2005, 9-34.

30 Por. M. Gogacz, Filozoficzne aspekty mistyki. Materiały do filozofii mistyki, Warszawa 1985, 3-44, 71-74, 110-114. 


\section{ETYKA}

Inne pole rozwijania filozofii tomistycznej stanowi etyka, rozumiana tu w sensie etyk szczegółowych i stosowanych, w których formułuje się zagadnienia bardziej konkretne dla gatunkowo określonych kategorii moralnych aktów ludzkich i zachodzi w nich konieczność odwoływania się do zasad ogólniejszych z zakresu wielu dyscyplin filozoficznych ${ }^{31}$. Zagadnienia te są poruszane zazwyczaj w kontekście spraw aktualnych, ważnych dla człowieka, wymagających pogłębionej analizy filozoficznej, zgodnie np. z podejściem św. Tomasza z Akwinu, którego etyka zawodowa rodziła się w związku ze zmianą form wymiany towarowej w XIII wieku².

Etyka tego rodzaju pojawia się przy okazji rozpatrywania stosunku człowieka do przyrody, czyli w etyce środowiskowej, o której już wspomniano wyżej przy okazji skrótowego omawiania praktycznej filozofii przyrody. Głównym polem jej zainteresowań jest - zgodnie z najogólniejszym podziałem omawianej nauki - etyka osobowa i społeczna, które posiadają jeszcze bardziej partykularne formy i w których zachodzi konieczność zastosowania ogólniejszych zasad filozoficznych.

W przypadku etyki osobowej chodzi np. o stosunek do życia ludzkiego, jego ochrony od chwili poczęcia do naturalnej śmierci. Nie jest to problem nowy, ale współcześnie rozpatruje się go często w ramach bioetyki, w związku z nowymi możliwościami i próbami ingerencji człowieka w życie ludzkie, w kontekście etyki ogólnej, antropologii filozoficznej i filozofii religii, które uzasadniają kategorię godności osoby ludzkiej, wartość życia ludzkiego, jego pochodzenie od Boga ${ }^{33}$.

31 Por. T. Ślipko, Zarys etyki szczegółowej, t. 1, Kraków 2002, 5, 12.

32 Por. S. Swieżawski, dz. cyt., 209.

33 Por. T. Ślipko, Kara śmierci z teologicznego i filozoficznego punktu widzenia, Kraków 2002, 116-122; Tenże, Za czy przeciw życiu. Pokłosie dyskusji, Kraków - Warszawa 1992, 26-27; T. Biesaga, Status embrionu ludzkiego - stanowisko personalizmu ontologicznego, w: Bioetyka polska, red. T. Biesaga, Kraków 2004, 257-264; Tenże, Początki bioetyki, jej 
Ważną częścią składową etyki osobowej stanowi też etyka seksualna, konieczna szczególnie w najnowszych czasach, w których sfera życia intymnego została oderwana od płodności i pogłębionej miłości, od trwałego związku międzyosobowego pomiędzy kobietą a mężczyzną. Zgodnie m.in. z kierunkiem, jakiej jej nadał Karol Wojtyła, zachodzi w niej konieczność odwoływania się nie tylko do zasad etyki ogólnej, ale też do filozoficznej wizji człowieka, jego natury i praw, w której znajdują swoje właściwe miejsce i adekwatne wyjaśnienie sprawy odmiennej płci, rozumienia miłości, wolności, roli kultury ${ }^{34}$.

Do szczegółowej etyki społecznej wchodzą z kolei zagadnienia związane z normami dotyczącymi „metafizyki społeczności”, obejmujące etykę społeczności naturalnych, umownych (zawodowych), jak małżeństwa, rodziny, narodu, państwa, społeczności międzynarodowych. Zagadnienia etyczne z nimi związane - choć nienowe - nabierają szczególnego znaczenia w niektórych okresach historii, także współczesnej, w którym aktualnymi sprawami są: kryzys trwałości więzi małżeńskich, stosunek do patriotyzmu, problemy społeczne (głód, wyzysk, migracja, starzenie się społeczeństwa europejskiego). W takich przypadkach pojawia się konieczność odwołania się do koncepcji natury ludzkiej; pojęcia godności osoby ludzkiej; struktury, pochodzenia i celu bytu społecznego; norm moralnych i kwestii istnienia Boga. Niezastosowanie tego swoistego klucza interpretacyjnego powoduje, że zjawiska te będą mało zrozumiałe i nie znajdą właściwego rozwiązania ${ }^{35}$.

rozwój i koncepcja, w: Podstawy i zastosowania bioetyki, red. T. Biesaga, Kraków 2001, $11-25$.

34 Por. K. Wojtyła, Miłość i odpowiedzialność, red. T. Styczeń i inni, Lublin 1986, 15; T. Ślipko, Życie i płeć człowieka, Kraków 1978, 6, 122-206, 240; Tenże, 9 dylematów etycznych, Kraków 2010, 50-63.

35 Por. T. Ślipko, Zarys etyki szczegółowej, t. 2, Kraków 1981, 17-58, 151-195; M. Gogacz, Życie społeczne w duchu Ewangelii. O nauczaniu społecznym Kościoła z Mieczysławem Gogaczem rozmawia Stanisław Krajski, dz. cyt., 13-15, 27-39. 


\section{ZAKOŃCZENIE}

Artykuł był próbą uzasadnienia - na przykładzie Polski - że jednym $z$ podstawowych sposobów rozwijania filozofii tomistycznej jest podejmowanie tematów bardziej szczegółowych, rozpatrywanych łącznie w dyscyplinach filozoficznych, które można określić jako metafizyki szczegółowe i stosowane. Nazwy te odpowiadają ich charakterowi metodologicznemu i epistemologicznemu. Cechą charakterystyczną dla nich jest bowiem zawężone pole badań oraz wykorzystywanie metod, zasad i ustaleń innych nauk filozoficznych wobec nich nadrzędnych, szczególnie metafizyki ogólnej. W związku $\mathrm{z}$ zastosowaniem $\mathrm{w}$ nich fundamentalnego aspektu poznania, tworzą one typ najbardziej podstawowej, fundamentalnej nauki, taką formę ludzkiej myśli, którą można utożsamiać z filozofią w sensie klasycznym, której podstawową postacią jest obecnie tomizm.

Metafizyka tego rodzaju, czyli szeroko pojęte studium tego, co jest najbardziej istotne w zakresie realnej rzeczywistości, odnosi się do wszelkich teorii podstawowych typów przedmiotów w sferze natury i kultury, zakresowo węższych w stosunku do metafizyki ogólnej. Jako zaś typowe nauki filozoficzne, na gruncie których istnieje największa możliwość ich rozwijania, podano filozofię przyrody, antropologię filozoficzną oraz niektóre formy filozofii ludzkiego działania, jakimi są religia i moralność.

W trakcie ogólnej prezentacji wspomnianych dyscyplin wskazywano zarówno na tematy, jakie były już podejmowane przez wielu przedstawicieli myśli tomistycznej w Polsce, jak i na takie, jakie są możliwe do podjęcia, zgodnie $\mathrm{z}$ kierunkiem generalnie już wyznaczonym. Rozważania filozoficzne tego rodzaju pozwalają na dogłębne rozumienie spraw leżących zasadniczo poza polem zainteresowania metafizyki ogólnej, czyli bardziej konkretnych, aktualnych, ale wkomponowanych w perspektywę szerszą czy całościową. Taki typ poznania jest o tyle cenny współcześnie, że wiele obecnych problemów światopoglądowych, dyskusji na temat świata, przyrody, człowieka 
i kultury nie jest $z$ reguły umieszczanych wyraźnie w perspektywie metafizycznej, czyli w ramach analizy najbardziej fundamentalnej i całościowej.

\section{BIBLIOGRAFIA}

Biesaga T., Poczatki bioetyki, jej rozwój i koncepcja, w: Podstawy i zastosowania bioetyki, red. T. Biesaga, Wyd. Nauk. PAT, Kraków 2001, 11-25.

Biesaga T., Status embrionu ludzkiego - stanowisko personalizmu ontologicznego, w: Bioetyka polska, red. T. Biesaga, Wyd. Nauk. PAT, Kraków 2004, 257-264.

Bronk A., Metodologiczny status nauk o religii, w: Filozofia religii, red. S. Janeczek, Wyd. KUL, Lublin 2012, 15-37.

Buczkowska J., Lemańska A., Wprowadzenie, w: Stwarzanie i ewolucja, red. J. Buczkowska, A. Lemańska, Wyd. UKSW, Warszawa 2002, 7-18.

Dyk W., Kreacja i ewolucja w świetle praw przyrody, w: Stwarzanie i ewolucja, red. J. Buczkowska, A. Lemańska, Wyd. UKSW, Warszawa 2002, 56-78.

Dyk W., Geneza duszy ludzkiej w kontekście teorii ewolucji, w: Metafizyczne i antropologiczne zatożenia filozofii religii, red. P. Moskal, Wyd. KUL, Lublin 2007, 103-134.

Ganowicz-Bączek A., Spór o etykę środowiskowa, Wyd. WAM, Kraków 2009.

Gogacz M., Cztowiek i jego relacje. Materiaty do flozofii cztowieka, Wyd. ATK, Warszawa 1985.

Gogacz M., Filozoficzne aspekty mistyki. Materiaty do filozofi mistyki, Wyd. ATK, Warszawa 1985.

Gogacz M., Życie spoteczne w duchu Ewangelii. O nauczaniu spotecznym Kościota z Mieczystawem Gogaczem rozmawia Stanistaw Krajski, Episteme 59(2006), red. A. Andrzejuk, Olecko 2006.

Hajduk Z., Filozofia przyrody, filozofia przyrodoznawstwa, metakosmologia, TN KUL, Lublin 2007.

Hajduk Z., Koncepcje filozofii przyrody, w: Filozofia przyrody, red. S. Janeczek i inni, Wyd. KUL, Lublin 2013, 15-29.

Heller M., Filozofia przyrody. Zarys bistoryczny, Wyd. Znak, Kraków 2004.

Heller M., Logos wszechświata. Zarys filozofii przyrody, Wyd. Znak, Kraków 2013. Jaworski M., Problem filozofii religii, w: Studia z filozofii Boga, religii i człowieka, red. J. Sochoń, Wyd. UKSW, Warszawa 2002, 116-141.

Jaworski M., Od filozofii religii do eidos Kościota. Wybór pism filozoficznych, t. 3, red. K. Mikucki, Wyd. UPJPII, Kraków 2018. 
Kamiński S, O naturze filozofii, w: Tenże, Jak filozofowač?, red. T. Szubka, TN KUL, Lublin 1989, 45-53.

Kamiński S., Osobliwość metodologiczna teorii bytu, w: Tenże, Jak filozofować?, red. T. Szubka, TN KUL, Lublin 1989, 71-87.

Kamiński S., Dziedziny teorii bytu, w: Tenże, Jak filozofować?, red. T. Szubka, TN KUL, Lublin 1989, 177-194.

Kamiński S., Metody wspótczesnej metafizyki, w: Tenże, Filozofia i metoda, red. J. Herbut, TN KUL, Lublin 1993, 41-122.

Kamiński S., O podstawach unifikacji nauk, w: Tenże, Metoda i jezzyk, red. U. M. egleń, TN KUL, Lublin 1994, 435-448.

Kamiński S., Wspótczesne metody metafizyki, w: Tenże, Filozofia i metoda, red. J. Herbut, TN KUL, Lublin 1993, 123-131.

Kieroń Z., Wróblewski Z., Filozofia przyrody a wspótczesna kultura, w: Filozofia przyrody, red. S. Janeczek i inni, Wyd. KUL, Lublin 2013, 283-299.

Kloskowski K., Filozofia erwolucji i filozofia stwarzania, t. 1: Między ewolucją a stwarzaniem, Wyd. ATK, Warszawa 1999.

Kłósak K., Dusza ludzka w perspektywach filozofii przyrody i metafizyki, Analecta Cracoviensia 10(1978), 29-47.

Kłósak K., Z teorii i metodologii fllozofi przyrody, Wyd. Księgarnia Św. Wojciecha, Poznań 1980.

Kowalczyk S., Zarys fllozofii cztowieka, Wyd. Diecezjalne, Sandomierz 2002.

Kowalczyk S., Antropologia fllozoficzna - koncepcja, metody, problematyka, w: Antropologia, red. S. Janeczek, Wyd. KUL, Lublin 2010, 17-42.

Krąpiec M.A., Zdybicka Z.J., O tomistycznej drodze poznania Boga, w: Aby poznać Boga i cztowieka, cz. I: O Bogu dzis, red. B. Bejze, Wyd. Sióstr Loretanek, Warszawa 1974, 71-83.

Krąpiec M.A., Cztowiek-Kultura-Uniwersytet, red. A. Wawrzyniak, Wyd. KUL, Lublin 1982.

Krąpiec M.A., Cztowiek i polityka, red. A. Maryniarczyk, Polskie Tow. Tomasza z Akwinu, Lublin 2007.

Krąpiec M.A., Cztowiek i prawo naturalne, Polskie Tow. Tomasza z Akwinu, Lublin 2009.

Latawiec A., Jak nauczać filozofii przyrody ożywionej?, w: Filozofia przyrody, red. S. Janeczek i inni, Wyd. KUL, Lublin 2013, 443-460.

Lemańska A., Praktyczna filozofia przyrody alternatywa klasycznej filozofii przyrody?, Studia Philosophiae Christianae 33(1997)1, 133-138.

Lemańska A., Filozofia przyrody a nauki przyrodnicze, w: Filozofia przyrody, red. S. Janeczek i inni, Wyd. KUL, Lublin 2013, 31-52. 
Lenartowicz P., Czy empiria biologiczna ma jakieś znaczenie dla filozofii cztowieka?, w: Antropologia, red. S. Janeczek, Wyd. KUL, Lublin 2010, 237-272.

Eukomski J., Próba zbudowania chrześcijańskiej etyki środowiska naturalnego, Wyd. Jedność, Kielce 2000.

Maryniarczyk A., Tomizm egzystencjalny a dziśfilozofii, w: Filozoforwaí dzis. Z badań nad flozofia najnowsza, red. A. Bronk, Wyd. TN KUL, Lublin 1995, 283-300.

Maryniarczyk A., Aktualność tomizmu, w: Wprowadzenie do filozofii, red. E. Eupina i inni, Wyd. KUL, Lublin 1998, 705-739.

Maryniarczyk A., Metafizyka w ekologii, Wyd. KUL, Lublin 1999.

Mączka J., Uwagi na temat przedmiotu fllozofii przyrody, w: Filozofia przyrody, red. S. Janeczek i inni, Wyd. KUL, Lublin 2013, 53-67.

Mikucki K., Kierunki badań fllozoficznych nad religiq w ujęciu Mariana Jaworskiego, w: Studia Leopoliensia 11(2018), 39-66.

Morawiec E., Podstawowe zagadnienia metafizyki klasycznej, Wyd. ATK, Warszawa 1998.

Moskal P., Problem genezy religii. Aspekty filozoficzne i teologiczne, w: Filozofować w kontekście teologii. Religia - Natura - Easka, red. P. Moskal, Wyd. KUL, Lublin 2003, 9-19.

Moskal P., Pytanie o religięprawdziwa, w: Filozofować w kontekście teologii. Problem religii prawdziwej, red. P. Moskal, Wyd. KUL, Lublin 2004, 11-23.

Moskal P., Teza teistyczna, w: Filozofowaí w kontekście teologii. Problem religii prawdziwej, red. P. Moskal, Wyd. KUL, Lublin 2004, 25-36.

Moskal P., Filozofia Objawienia, w: Objawienie, red. P. Moskal, Wyd. KUL, Lublin 2005, 9-34.

Moskal P., Religia i prawda. Filozofia religii, apologia religii, diagnostyka religii, w: Filozofia religii, red. S. Janeczek, Wyd. KUL, Lublin 2012, 317-335.

Rusecki M., Cud w chrześcijaństwie, TN KUL, Lublin 1996.

Stępień A. B., W poszukiwaniu istoty cztowieka. Z fenomenologii i metafizyki bytu ludzkiego, w: Aby poznać Boga i cztowieka, cz. 2: Ocztowieku dzis, red. B. Bejze, Wyd. Sióstr Loretanek, Warszawa 1974, 61-94.

Swieżawski S., Święty Tomasz na nowo odczytany, Wyd. Znak, Kraków 1983.

Ślipko T., Życie i płé́ człowieka, Wyd. WAM, Kraków 1978.

Ślipko T., Zarys etyki szczegótowej, t. 1-2, Wyd. WAM, Kraków 1981.

Ślipko T., Za czy przeciw życiu. Poktosie dyskusji, Wyd. Ośrodek Chrześcijańskiej Myśli Społecznej „Augustinum”, Kraków - Warszawa 1992.

Ślipko T., Kara śmierci z teologicznego iflozoficznego punktu widzenia, Wyd. WAM, Kraków 2002.

Ślipko T, 9 dylematów etycznych, Wyd. Petrus, Kraków 2010. 
Świeżyński A., Prawa nauki a możliwość zachodzenia zjawisk cudownych w kontekście zagadnienia naukowej niewyjaśnialności cudu, w: Filozofia przyrody, red. S. Janeczek i inni, Wyd. KUL, Lublin 2013, 413-439.

Wnuk M., Zykubek A., Pojęcie, natura i geneza życia, w: Filozofia przyrody, red. S. Janeczek i inni, Wyd. KUL, Lublin 2013, 71-85.

Wojciechowski T., Zarys filozofii przyrody ożywionej, Wyd. UO, Opole 1997.

Wojtyła K., Osoba i czyn, Wyd. PTT, Kraków 1985.

Wojtyła K., Mitość i odpowiedzialność, red. T. Styczeń i inni, Wyd. TN KUL, Lublin 1986.

Zdybicka Z.J., Udziat filozofii w określaniu prawdziwości religii, w: Filozofować w kontekście teologii. Problem religii prawdziwej, red. P. Moskal, Wyd. KUL, Lublin 2004, 37-49.

Ziemiański S., Celowość wedtug Arystotelesa i św. Tomasza z Akwinu, w: W poszukiwaniu istoty życia. Pamięci ks. prof. Szczepana Ślagi, red. G. Bugajak, A. Latawiec, Wyd. UKSW, Warszawa 2005, 159-176.

Zon J., Ewolucja i ewolucjonizm, w: Filozofia przyrody, red. S. Janeczek i inni, Wyd. KUL, Lublin 2013, 87-113.

\section{PERSPECTIVES FOR THE DEVELOPMENT OF THOMISTIC PHILOSOPHY IN POLAND}

Abstract. This article discusses the perspectives for the development and thus the future of Thomistic philosophy in Poland. This issue is considered with respect to specific studies outside the main object of interest of general metaphysics, and which take the form of detailed and applied metaphysics. While the former refers to a narrow field of research, the second uses the achievements of other and more basic philosophical sciences, including general metaphysics.

Metaphysics of this kind constitutes a broadly understood study of what is most fundamental not for being as such, but for all basic types of objects in the realms of nature and culture. It is not, however, alternative to general metaphysics, which explores reality in its transcendental dimension. On the contrary, by using its achievements it establishes a connection with it and constitutes its necessary complement. By developing this metaphysics, this article illustrates the philosophy of nature, philosophical anthropology and two forms of the philosophy of human action, namely, religion and morality. Some of the topics they suggest have already been taken up by many representatives of Thomist thought in Poland, while others can be the object of future research.

The realization of these forms of metaphysics corresponds not only to the structure of a pluralistic reality and an interrelated series of dependencies, but also highlights current and new problems that require a thorough and comprehensive approach, which can only be provided by a metaphysical perspective within Thomistic philosophy. 
Keywords: development of Thomistic philosophy, detailed and applied metaphysics

\section{KAZIMIERZ MIKUCKI}

kazimierzmikucki@wp.pl

Instytut Teologiczny Archidiecezji Lwowskiej

Lwowska 62, 79491 Lwów, Ukraina

DOI: 10.21697/spch.2019.55.3.02 